\title{
Construções idiomáticas com o verbo pegar: uma abordagem sociocognitiva
}

\author{
Leosmar Aparecido da Silva*
}

\begin{abstract}
Resumo
Este artigo tem o objetivo de analisar os usos do verbo pegar, especialmente em construções idiomáticas, em dados de língua falada. Metodologicamente, foram coletadas ocorrências do verbo pegar no corpus do Fala Goiana, gravado e transcrito pelo Grupo de Estudos Funcionalistas da UFG. Guiado pelas considerações teóricas da linguística cognitiva, o artigo analisa os usos de pegar em construções idiomáticas, considerando-se a frequência de uso, a mudança de sentido pelo uso, os graus de transparência e opacidade de algumas construções e a aplicação de esquemas imagéticos. Os resultados deste trabalho revelaram que o verbo pegar apresenta alta frequência de uso, o que contribuiu para que ele espraiasse seu estatuto semântico e suas funções lexicais e funcionais. $O$ estudo revelou também que as construções idiomáticas apresentam grau de opacidade ora baixo ora alto. O estudo pode contribuir para a ampliação da gama de estudos sobre particularidades linguísticas de construções idiomáticas do português do Brasil.

Palavras-chave: Cognição. Construção. Idiomaticidade. Metaforização. Verbo pegar.
\end{abstract}

\section{Introdução}

Interessa à linguística cognitiva descrever os usos da língua a partir da percepção e da conceptualização humana em relação ao mundo. A língua, nesse sentido, está diretamente ligada à atividade humana e à realidade sociocultural. Para os sociocognitivistas, a sintaxe não constitui um componente autônomo da mente, ou seja, ela não é independente de outras faculdades mentais, tal como concebiam os gerativistas. Ao contrário, a sintaxe é vista como um dos componentes da rede construcional da mente.

Como as construções idiomáticas foram consideradas durante muito tempo como exceções sintáticas ou curiosidades semânticas, é relevante uma investigação

* Doutor em Estudos Linguísticos. Professor da Universidade Federal de Goiás. E-mail: <leosmarsilva@ hotmail.com>. 
sobre tais construções, tendo como fundamentação uma teoria relativamente nova, que atenta para questões sem respostas durante muito tempo. Em $O$ menino pegou a bola e Maria pegou gripe, há uma configuração sintática semelhante [SN1 V SN2], contudo, o papel semântico de cada um dos atores da cena discursiva se diferencia, porque, em cada sentença, há esquemas abstratos gerais (FERRARI, 2009), baseados na experiência física do falante no contato com o mundo, e não "regras algorítmicas de manipulação de símbolos" (op. cit., p. 129).

Em vista dessas considerações, este artigo tem o objetivo mais de analisar, no corpus do Fala Goiana, gravado e transcrito por integrantes do Grupo de Estudos Funcionalistas (GEF), da Universidade Federal de Goiás (UFG), os usos das construções idiomáticas encabeçadas pelo verbo pegar. São objetivos também deste artigo verificar a frequência do verbo no corpus e a sua consequente produtividade; apontar aspectos sintáticos, semânticos e pragmáticos observáveis em alguns usos; investigar como o fluxo básico de mudança motivado pelo uso se aplica ao verbo pegar; identificar uma tipologia de usos do verbo, dando-se maior atenção às construções idiomáticas; tecer considerações sobre os graus de transparência e opacidade das construções idiomáticas e; identificar a aplicação ou não - de esquemas imagéticos em algumas construções.

Para além da introdução e das considerações finais, o artigo está dividido em três seções. Na primeira seção, faz-se uma revisão teórica tanto sobre a linguística cognitiva quanto sobre as construções idiomáticas. Na segunda, descrevem-se os procedimentos metodológicos adotados na pesquisa. Por fim, na terceira, faz-se a análise e discussão dos dados.

\section{Cognição, rotinização e construções idiomáticas}

Um dos postulados da linguística cognitiva, segundo Croft e Cruse (2004, p. 1), é de que a gramática é uma conceptualização, isto é, constitui uma configuração de conhecimento que verifica como se constrói o universo linguístico na mente com base nas experiências vividas.

Isso significa que a conceptualização do mundo está fortemente ligada aos padrões culturais. Langacker (2002, p. 138) afirma que "a cultura tem inúmeras manifestações na gramática". ${ }^{1} \mathrm{O}$ autor afirma também que a linguagem e a cultura

1 Culture has myriad manifestations in grammar. (Tradução nossa.) 
são facetas imbricadas da cognição. Assim, a diversidade linguística e cultural pode ser vista como desenvolvimento de recursos compartilhados que refletem aspectos universais do corpo humano, da mente e da experiência. Pensando nisso, um dos sentidos que se pode depreender do verbo pegar, por exemplo, em sua forma-fonte, é a relação tátil do falante, própria de sua constituição corpórea, com os objetos e com os eventos do mundo.

Assim, os estudos sobre cognição implicam a inclusão e a valorização de fatores sociais, interacionais e culturais, visto que as mentes individuais não são entidades autônomas. É por meio da interação social, mediada pela cultura, que a cognição e a linguagem surgem, desenvolvem-se e estruturam-se.

Outro postulado da linguística cognitiva é o de que o conhecimento da língua surge da língua em uso. Os aspectos pragmáticos que estão envolvidos na produção do ato linguístico constituem importante expediente para o processamento do pensamento, da palavra, de construções. Assim, as categorias e estruturas presentes nos níveis semântico, sintático, morfológico e fonológico são construídas pela cognição humana em forma de enunciados específicos em situações específicas de uso. Nos termos de Croft e Cruse (2004), já não são mais as condições de verdade que determinam as sentenças, tal como postula a semântica formal, mas as condições de uso dessas sentenças, integradas a uma comunidade linguística, dotada de padrões culturais.

A partir do surgimento da linguística cognitiva, muitos estudos e trabalhos de pesquisa foram desenvolvidos, considerando-se tanto o primeiro postulado (FERRARI, 2009; SILVA, 2012) quanto o segundo, o de que o conhecimento da língua surge da língua em uso, (BARRETO, 1999; RODRIGUES, 2004; BYBEE, 2010; OLIVEIRA; ROSÁRIO, 2015).

Também tem havido crescente interesse em se estudar as construções idiomáticas (NUNBERG; SAG; WASOW, 1994; FILLMORE; KAY; O'CONNOR, 1988; VALE, 1999; CROFT; CRUSE, 2004), já que, durante muito tempo, elas foram consideradas exceções no domínio da sintaxe por não haver ainda teorias que pudessem descrevê-las como fenômeno sintático, semântico e pragmático.

Em relação ao verbo pegar, existem, no Brasil, trabalhos desenvolvidos, principalmente, por Rodrigues $(2004,2006)$ e por Sigiliano $(2006,2008)$, que enfocam tal verbo em construções conhecidas como construções do tipo foi fez (CFF), que se formam "a partir de uma sequência mínima de dois verbos, V1 e V2, em que V1 e V2 partilham sujeito e flexões modo-temporais e número-pessoais" 
(cf. GONÇALVES; LIMA-HERNANDES; CASSEB-GALVÃO, 2007, p. 120).

Rodrigues (2004) considera que construções do tipo eu peguei e saí têm configuração sintática similar à da coordenação, visto que se formam por meio de dois verbos flexionados e ligados pelo juntivo $e$. Chega à conclusão de que, apesar da semelhança com as cláusulas coordenadas, tais construções "exibem propriedades que não são partilhadas por nenhuma outra construção do português, o que [as] caracteriza como construção gramatical singular" (RODRIGUES, 2004, p. 38). Em vista disso, mostra a vantagem de se usar um modelo construcional, em que se demonstre a estreita relação entre construções mais idiomáticas com construções mais familiares.

Em trabalho de 2006, Sigiliano defende que o verbo pegar pode funcionar como verbo pleno, como introdutor de discurso reportado ou de verbos de ação, como marcador de aspecto inceptivo e/ou interativo e que, em todas essas funções, subjaz a noção de movimento. Sigiliano (2008) procura demonstrar as noções de movimento e mudança inerentes ao verbo pegar em construções diversas. Para isso, elabora seis esquemas por meio dos quais descreve os diversos usos de pegar em que tais noções estão presentes, além de um sétimo esquema, mais abstrato, em que haveria um movimento virtual no discurso. Os esquemas propostos por Sigiliano (2008) estão resumidos no quadro 1, a seguir:

QUADRO 1 - Resumo dos esquemas com o verbo pegar, propostos por Sigiliano (2008)

\begin{tabular}{|l|l|}
\hline \multicolumn{1}{|c|}{ ESQUEMA } & \multicolumn{1}{|c|}{ EXEMPLO } \\
\hline $\begin{array}{l}\text { Esquema 1: Há um duplo movimento } \\
\text { realizado entre os argumentos A e B. O } \\
\text { movimento evolui para que B se insira } \\
\text { no contêiner de A. }\end{array}$ & Peguei uma sanfona. \\
\hline $\begin{array}{l}\text { Esquema 2: A "escolhe" B e o } \\
\text { encaminha para um contêiner } \\
\text { determinado. }\end{array}$ & Vou pegar outra firma. \\
\hline $\begin{array}{l}\text { Esquema 3: O constituinte B vai em } \\
\text { direção a A e se insere no contêiner } \\
\text { de A. }\end{array}$ & Será que a madeira pegou fogo? \\
\hline
\end{tabular}

$2 \mathrm{~A} \mathrm{e} \mathrm{B} \mathrm{correspondem,} \mathrm{segundo} \mathrm{a} \mathrm{autora,} \mathrm{à} \mathrm{ordem} \mathrm{dos} \mathrm{constituintes} \mathrm{participantes} \mathrm{da} \mathrm{cena.} \mathrm{A} \mathrm{corresponde,}$ portanto, ao sujeito, e B, ao objeto. 


\begin{tabular}{|l|l|}
\hline $\begin{array}{l}\text { Esquema 4: O constituinte A se } \\
\text { movimenta até B e se insere no } \\
\text { contêiner de B. }\end{array}$ & Nós íamos pegar um ônibus. \\
\hline $\begin{array}{l}\text { Esquema 5: O constituinte A realiza } \\
\text { movimento único em direção a B, B B } \\
\text { se insere no contêiner de A. }\end{array}$ & Eu te pego de carro. \\
\hline $\begin{array}{l}\text { Esquema 6: Movimento duplo de } \\
\text { A para B e vice-versa, e ambos } \\
\text { compartilham um mesmo contêiner. }\end{array}$ & $\begin{array}{l}\text { O Vasco pega outro Rubro-Negro } \\
\text { hoje. }\end{array}$ \\
\hline $\begin{array}{l}\text { Pegar no discurso: O turno de } \\
\text { fala é movimentado/mudado nas } \\
\text { construções com o verbo pegar }+ \\
\text { verbo dicendi. }\end{array}$ & $\begin{array}{l}\text { Eu peguei e falei com ele, “ó eu } \\
\text { quebiaçaqui que vou ter que passar } \\
\text { a fiaça }\end{array}$ \\
\hline
\end{tabular}

Embora os trabalhos de Rodrigues (2004, 2006) e de Sigiliano (2006, 2008) enfoquem alguns usos de pegar e suas funções lexicais, gramaticais e discursivas, nenhum deles trabalha, especificamente, com a idiomatização de tal verbo. Dado que isso ocorre, este trabalho se propõe, então, fazer uma abordagem que enfoque propriedades de idiomatização de pegar. Como os esquemas 3, 4 e 5 de Sigiliano (2008) tratam de usos mais ou menos idiomatizados, eles servirão de base para a análise dos dados desta investigação.

Para compreendermos o processamento da inovação linguística e, consequentemente, o surgimento das construções idiomáticas, poder-se-ia fazer um paralelo, tal como o que propõe Bizzocchi (2008), com a teoria da evolução.

Para Bizzocchi (2008), na Teoria Evolucionista, as moléculas de DNA, presentes nos seres vivos, produzem cópias de si mesmas. É comum que nesse processo ocorram falhas, as quais resultam numa reprodução imperfeita da molécula original. A constante replicação do DNA faz com que as mutações se acumulem. Depois de algumas gerações, os organismos já apresentam alterações significativas. O surgimento de novos usos linguísticos é, segundo o autor, parecido com a mutação genética, com a diferença de que esses novos usos não são tratados como falha. Cada situação nova de interação verbal, segundo Bizzocchi (2008), cria condições para que o falante faça uso de velhas construções. Cada vez que construção é usada, ela é, minimamente, diferente do primeiro uso, ou formafonte, tanto na forma quanto no significado. Tanto o uso antigo como o inovador 
convivem por um certo período de tempo. Depois, num processo de "seleção cultural", uma das formas torna-se vencedora e, com o tempo, pode fazer parte do léxico ou da gramática comum dos falantes de determinada língua. $\mathrm{O}$ autor conclui que o processo de adaptação da nova construção linguística às necessidades sociais e culturais do falante contribui para que ela tenha funcionalidade e permaneça na língua.

Tomando por base a assertiva cognitivista de que a compreensão e o armazenamento dos dados da experiência são fatores que potencializam a criação de novas construções na língua, pode-se afirmar que certas palavras e/ ou construções, e não outra(s), teriam maior tendência de espraiarem seu estatuto semântico, alterarem suas relações sintáticas e serem bastante frequentes, para, enfim, integrarem o léxico ou tornarem-se verbos auxiliares, itens relacionais, afixos, por meio de processos como a metáfora e a metonímia.

Quanto maior a frequência de uso de palavras pelo falante, menor esforço cognitivo ele fará para evocá-las no discurso. É como se os caminhos neurais já estivessem estabelecidos e não precisasse mais haver a abertura de novos. É por isso que um dos critérios para que uma expressão metafórica se cristalize é a rotinização de seu uso. Além disso, a frequência de uso revela o estágio de luta para a sobrevivência de duas ou mais formas, tal como afirma Bizzocchi (2008).

Givón (1995) apresenta a noção de marcação, que é importante para que se estabeleça o fluxo básico de mudança motivado pelo uso. Para ele, quanto maior a complexidade cognitiva de uma forma ou expressão, menor será sua frequência e maior a sua complexidade estrutural. Na mesma direção, quanto menor for a complexidade cognitiva de uma forma ou expressão, maior será sua frequência e menor será a sua complexidade estrutural. Essas relações podem ser representadas pelo seguinte esquema:

QUADRO 2 - Fluxo básico de mudança motivado pelo uso

$>$ complexidade cognitiva $<$ frequência $>$ complexidade estrutural. $<$ complexidade cognitiva $>$ frequência $<$ complexidade estrutural. ${ }^{3}$

A complexidade estrutural está diretamente relacionada à complexidade cognitiva e inversamente relacionada à frequência de uso. Assim, é possível verificar como o sistema conceptual humano se forma: o modo como representamos mentalmente os eventos é básico para a organização do discurso e da gramática

3 Em que o sinal "<" significa menor e o sinal ">” significa maior. 
das línguas, ou seja, a organização das colônias neurais no cérebro e a organização da sintaxe das línguas possuem semelhanças estruturais.

As construções ${ }^{4}$ idiomáticas, objeto deste estudo, são unidades lexicais ou gramaticais maiores que a palavra. Segundo Croft e Cruse (2004), elas são, em algum aspecto, idiossincráticas, posto que algumas delas (de mais a mais, por exemplo) fogem às regras usuais da gramática.

Para Nunberg, Sag e Wasow (1994), uma característica prototípica das construções idiomáticas é a convencionalidade. Assim, o significado ou o uso dessas construções não pode ser previsto quando um de seus elementos aparece isolado dos outros. É consenso entre os linguistas que, no plano sintático, as construções idiomáticas são semelhantes às não idiomáticas. Já no plano cognitivo, elas são interpretadas pelos falantes/ouvintes pela totalidade de seus componentes e não pelas partes que as constituem.

Além da convencionalidade, as construções idiomáticas apresentam outras características. Dentre as que são citadas por Croft e Cruse (2004) estão:

a) a inflexibilidade: propriedade sobre a qual repousa a ideia de que as construções idiomáticas apresentam restrição sintática;

b) a figuração: em geral o significado é metafórico, figurativo;

c) a proverbialidade: a descrição da atividade social é comparada com uma atividade concreta, o que permite a construção do provérbio;

d) a informalidade: tipicamente, a construção está associada com um registro ou estilo de fala informais;

e) a subjetividade: em geral há uma avaliação ou orientação afetiva para o que as construções idiomáticas descrevem.

Em favor da gramática de construções, Fillmore, Kay e O’Connor (1988) fazem algumas distinções como forma de caracterizar as construções idiomáticas.

A primeira distinção é entre as expressões combinando idiomaticidade e os sintagmas idiomáticos. As expressões combinando idiomaticidade são expressões idiomáticas em que parte do significado idiomático pode ser colocado em correspondência com as partes do significado literal, como em answer the door ("atender a porta"). Já os sintagmas idiomáticos não apresentam correspondência entre os dois significados, como em kick the bucket (morrer). Essa distinção corresponde à noção de transparência e opacidade. Quanto mais a construção estudo sobre as expressões idiomáticas em geral está ligado à gramática de construções. 
aproxima-se do significado literal tanto mais transparente ela será. Quanto mais a expressão distancia-se do significado literal, mais opaca ela será.

Fillmore, Kay e O'Connor (1988) distinguem também expressões gramaticais - que podem ser analisadas por regras gerais de sintaxe, mas são semanticamente irregulares, como spill the beans (divulgar a informação) - e expressĩes extragramaticais - que não podem ser analisadas por regras gerais da sintaxe, como all of a sudden (de repente).

Uma outra importante distinção é entre expressões esquemáticas e substantivas. Nas expressões esquemáticas, algum elemento ou os elementos são lexicalmente abertos, ou seja, podem se flexionar de algum modo, como em kicked the bucket ou kick the bucket. Nas expressões substantivas, não há elementos lexicalmente abertos, como em the X-er, the Y-er (the bigger... the harder).

Por fim, Fillmore, Kay e O'Connor (1988) distinguem expressões com e sem aspecto pragmático. As que possuem aspecto pragmático são as usadas em certos contextos pragmáticos como good morning, see you later. As que não possuem o aspecto pragmático são aquelas em que o aspecto pragmático é irrelevante para a estrutura da informação, como em all of a sudden.

Neves (2002) trata da delimitação de unidades lexicais e propõe estudar o comportamento de construções com verbo-suporte, que se distinguem de construções idiomáticas. Para a autora, há um continuum, que se inicia com construções livres, que possuem menor unicidade lexical, e termina com as construções idiomáticas, que possuem maior unicidade lexical. No meio do continuum, estão as construções com verbo-suporte. A maior ou menor unicidade lexical, apontada por Neves (2002), está relacionada à ideia de composicionalidade, caracterizada por Nunberg, Sag e Wasow (1994).

Para Fillmore, Kay e O'Connor (1988), quanto mais esquemática ou aberta é uma construção, tanto mais composicional ela será. Seguindo o mesmo raciocínio, quanto mais substantiva ou fechada é a construção, tanto mais não composicional ela será. Assim, por um lado, as construções "pegar uma gripe", "pegar um resfriado", "pegar uma tosse" são metafóricas, e ao mesmo tempo, são mais esquemáticas e mais composicionais, visto que os significados de "pegar" + "alguma enfermidade" somam-se para formar um todo de significação. Por outro lado, em "pegar no pé" (insistir, chatear), a expressão "no pé” não pode ser substituída por "na cabeça", "no braço", sob pena de a construção idiomática deixar de existir. Assim, "pegar no pé", além de ser uma metáfora altamente 
convencional, caracteriza-se por ser uma unidade lexical não composicional, visto que o sentido é depreendido pelo todo e não pelas partes, além de ser substantiva e com maior unicidade lexical.

Tanto nas construções idiomáticas lexicais quanto nas construções gramaticalizadas, há processos de metaforização e esvaziamento semântico das partes que compõem o todo. Nesse sentido, pode-se estabelecer uma aproximação entre construções idiomáticas e gramaticalização, mas deixando clara uma diferença: nas construções idiomáticas, há perda do significado dos itens individuais e ganho de um significado lexical global; na gramaticalização, há perda de significado lexical e ganho de funções gramaticais. Segundo Vale (1999, p. 165), "se os elementos das construções idiomáticas sofrem um esvaziamento de significado individualmente, isso se dá para que se crie um outro significado que tem como significante o conjunto idiomatizado desses elementos".

Feitas essas considerações teóricas, na próxima seção, descrevem-se os procedimentos metodológicos adotados na pesquisa.

\section{Procedimentos metodológicos}

Realizou-se, por meio desta pesquisa, de caráter descritivo e com abordagem qualitativa, um estudo em uma amostra de quatro inquéritos do corpus Fala Goiana, gravado e transcrito por integrantes do Grupo de Estudos Funcionalistas da Universidade Federal de Goiás e disponibilizado na página $<$ https://gef.letras. ufg.br/>. Cada inquérito tem aproximadamente sessenta minutos de gravação, e a transcrição total da amostra tem em torno de 42.300 palavras.

O conteúdo dos inquéritos constitui-se de narrativas de histórias de vida contadas por dois falantes do sexo masculino (um com 30 anos de idade e o outro com 72 anos de idade) e por duas falantes do sexo feminino (uma com 28 anos de idade e a outra com 70 anos de idade). Embora as variáveis de idade e sexo tenham sido diligentemente selecionadas de forma simétrica, a análise dos dados não tem uma abordagem sociolinguística. Isso não nos impediu, porém, de fazer algum tipo de consideração sociolinguística no decorrer do trabalho.

Utilizando-se do recurso localizar, no Word for Windows, procedeu-se à busca de ocorrências do verbo pegar, em todos os tempos e modos. Essas ocorrências foram transpostas para arquivo específico e, utilizando-se das considerações teóricas sobre as construções idiomáticas e guiados pelos objetivos específicos deste artigo, fez-se a análise dos dados. 
Caracterizado o corpus e definidos os critérios de análise, apresentam-se, a seguir, os resultados e discussões desta pesquisa.

\section{Análise dos dados: construções idiomáticas com o verbo pegar}

Do latim pücāre, a etimologia do verbo pegar, conforme Cunha (2010, p. 484), está ligada à ideia de "fazer aderir, prender, segurar". O falante pode usá-lo no sentido de segurar ou agarrar algum objeto, fazendo ou não uso da preposição, como em: pegar na mão de alguém, pegar uma xícara.

$\mathrm{Na}$ amostra utilizada do corpus Fala Goiana, foram encontradas 156 ocorrências do verbo pegar. Dessas ocorrências, 86 estão presentes na fala de colaboradores do sexo feminino e 70 na fala de colaboradores do sexo masculino, o que nos leva a crer que tanto falantes homens quanto falantes mulheres utilizam produtivamente tal verbo em diferentes funções. A maioria das ocorrências (107 delas) foi enunciada por falantes mais jovens, entre 25 e 35 anos de idade, o que sociolinguisticamente pode ser significativo.

Foi possível categorizar os usos em três tipos bastante recorrentes nos dados e que se mostram no quadro 3, a seguir:

QUADRO 3 - Tipos principais de construções com o verbo pegar no corpus principal

\begin{tabular}{|l|l|}
\hline \multicolumn{1}{|c|}{ TIPOS DE CONSTRUÇÕES } & \multicolumn{1}{|c|}{ DADOS } \\
\hline Verbo pegar pleno & $\begin{array}{l}\text { eu pegava água numa cisterna lá... } \\
\text { e essa cisterna era na casa dessa } \\
\text { PRIMA minha (Masc. 30 anos). }\end{array}$ \\
\hline Verbo pegar idiomatizado & $\begin{array}{l}\text { ele mim pegô no fraga... eu tava } \\
\text { xingando... (Masc. 30 anos.) }\end{array}$ \\
\hline $\begin{array}{l}\text { Verbo pegar em Construções foi e fez } \\
\text { (CFF) }\end{array}$ & $\begin{array}{l}\text { um dia... eu peguei saí... brincando } \\
\text { mais minha irmã e um primo meu... } \\
\text { (Fem., 28 anos). }\end{array}$ \\
\hline
\end{tabular}

Embora não tenham sido o objeto principal desta investigação, as CFF do tipo peguei (e) saí, peguei (e) falei totalizaram 36,53\% das ocorrências (57 de 156 delas). Um número considerável, já que, sozinha, essa construção quase chega a 
$40 \%$ da amostra, dado que pegar pleno e pegar idiomático apresentam nuanças sintático-semânticas bastante variadas. Os dados (1) e (2) a seguir evidenciam esse tipo de construção:

(1) na minha infância que tinha doze anos... bem perto da fazenda... BEM de frente a fazenda... eu peguei e falei pra ele [o pai]... falei pra ele... o senhor alembra o DIA que o senhor me deu uma lição ali ó... debaixo da árve bem naquela baxada... ele ficô calado... peguei e falei pra ele... porque que é que o senhor tá xingano... o exempro que o senhor me deu não foi esse... e o senhor acha que hoje o senhor xingá vai resolvê alguma coisa... eu acho que ( ) da idade do senhor tamém num acalha bem... acho que o senhor devia de pensar bem antes di dirigi a palavra... (Masc. 30)

(2) tava tudo arrumadim assim aí eu peguei e::: falei a não lá não... aí fechô... largô esse lote lá aí minha sogra falô assim é porque vocêis num pricisa... (Fem. 28)

Muito rotinizadas e abstratas, essas construções, conforme Gonçalves, Lima-Hernandes e Casseb-Galvão (2007), não carecem da explicitação do objeto de V1, mas têm a função gramatical(izada) de colocar em evidência o objeto de V2 subsequente. No caso de (1) e de (2), os objetos de V2 enfocados são o conteúdo do que o/a falante diz. Elas aparecem no texto também para garantir que haja fluxo de informação, ou seja, em quase todas as vezes que o falante relata um novo evento, ele faz uso do verbo pegar, além de indicar o movimento do turno da fala, conforme assegura Sigiliano (2008).

Considerando-se, agora, as construções idiomáticas que ocorreram no corpus, destaca-se pegar + meio de transporte, como se verifica em pegar o trem de ferro, em (3), a seguir:

(3) aí nós pegamo otro dia a tarde... pegô o trem de ferro di novo e vei até::: Leopodo do Bulhões... lá nóis ficamo treze dia... meu filho... cuzinhando numa enchorrada... minha vó fazia uma lata de... cuzinhava na lata de... de querosene... quelas latas de dezoito litro... né... (Fem. 70) 
Pegar o trem de ferro constitui uma expressão metafórica, que pode ter sido elaborada criativamente em analogia à ideia de que, assim como é possível pegar uma xícara, objeto de proporções menores que a pessoa, também é possível pegar um ônibus, objeto de maiores proporções. O que torna a construção "pegar o trem" metafórica e "pegar a xícara" não metafórica é o movimento do agente associado à dimensionalidade do objeto. A xícara, por ser um objeto pequeno, pode ser completamente manipulada pelas mãos do agente, o que não ocorre com o trem. O corpo todo é envolvido na ação, o que torna impossível conceber o verbo pegar, em pegar o trem, no sentido de segurar com as mãos. Embora seja uma construção metafórica, ainda há nela composicionalidade, visto que as partes "pegar" e "trem de ferro" conservam seus significados que, somados, formam uma construção transparente, dado que o grau de opacidade semântica ainda é pequeno. Como "ônibus" conserva ainda seu significado literal, tem-se, nos termos de Fillmore, Kay e O’Connor (1988), uma expressão combinando idiomaticidade. A possibilidade de substituição de um dos elementos da construção por outro de semelhante natureza semântica, como pegar um ônibus, pegar um táxi, é mais uma prova disso. Em (3), percebe-se ainda o esquema 4, proposto por Sigiliano, em que o constituinte A (nós) se movimenta até B (o trem de ferro) e se insere no contêiner. É uma metáfora baseada no esquema do contêiner, proposto por Johnson (1987).

Uma outra relação metafórica, um pouco mais abstrata que a anterior, é a que se verifica em (4):

(4) ele tá deveno muito... deve no banco... ele deve... vendeu a casa dele... boa qu/ele tinha... ele vendeu e taí desse jeito morano na casa da minha mãe... ajuda pagá água energia... e tá... então vive... pegano com Deus pra qui Deus um dia vai vai levantá a vida dele di novo... fazê as coisa que sempre ele gostô de fazê com a família... tê a casa dele di novo porque ele já teve duas casa... todas duas casa $\mathrm{BOa} .$. pra hoje ele num tê... num tê nenhuma... tá morano assim. (Fem. 33)

Embora o uso de pegar em (4) esteja um pouco distante do sentido-fonte desse verbo, existem explicações cognitivas que esclarecem o uso de pegar no sentido de "orar", "rezar". O verbo pegar pressupõe a relação de proximidade entre dois elementos, de modo que o segundo ajude a transformar de alguma forma o estado do primeiro. Em (4), haveria uma espécie de contêiner em que tanto A quanto B 
compartilham movimentos (esquema 5, de SIGILIANO, 2008). Deus, entendido culturalmente como imaterial, espírito, parece tornar-se mais corpóreo e mais próximo do falante quando se usa a forma verbal pegano no lugar de outra forma verbal como rezando, orando. Isso torna a construção linguística pragmaticamente expressiva e descreve bem a força ilocucional do dizer do falante. Acresce-se a isso o fato de o verbo ter sido usado na forma nominal do gerúndio, que torna o processo descrito menos télico e mais contínuo, e o fato de que tal verbo foi antecedido por outro de natureza aspectual frequentativa (vive).

Um dos critérios propostos por Wierzbicka, citada por Croft e Cruse (2004, p. 243) para verificar a idiomaticidade da expressão é a substituição de um dos elementos da construção por outro elemento de valor semelhante. A substituibilidade é a característica das construções de poderem substituir um de seus itens, mantendo-se o mesmo grau de uso e reconhecimento de sentido da construção. Se em (4), em vez de se dizer pegano com Deus, se dissesse segurando com Deus, apalpando com Deus, agarrando com Deus, a construção não seria produtiva, nem funcional. Isso atesta um certo grau de idiomaticidade da expressão. À semelhança de pegar o trem, pegar o ônibus, descrito em (3), o dado (4) tem flexibilidade substantiva do segundo elemento lexical, mas não do verbo pegar. Assim, poder-se-ia dizer "pegando com Cristo", "pegando com a Virgem Maria", "pegando com todos os santos". Observa-se, então, fixidez à esquerda e flexibilidade à direita no sintagma construcional, o que mostra que o centro da metaforização é o verbo pegar.

Como já comentado anteriormente, os itens linguísticos surgem, evoluem e acumulam modificações ao longo do tempo. Os seres humanos usam-nos com um outro item e os adaptam às novas circunstâncias de comunicação. É o que se pode verificar em (5) e (6), a seguir, em que a associação do verbo pegar com uma parte do corpo - o pé - gera o sentido de chatear, falar com insistência, aborrecer, enfadar. Nos dois usos, o "aborrecimento" carrega em si o traço de humor, graça:

(5) meu pai mesmo eu num cheguei a conhecê... i sempre minha mãe... sempre pegava no meu pé... falava que cê tem a cara do seu pai... (Masc. 30)

(6) ah [o mar] é bão... a primera coisa qu'eu fiz foi merguiá dento dágua bebê água pra vê se era salgada mesmo... aí vi qu'era salgada... vortei pra trais... gritei pra todo mundo... é salgada... o povo começô a pegá no pé. (Masc. 30) 
As relações entre o domínio do verbo pegar com o domínio da palavra pé que geraram o sentido de chatear podem ser explicadas talvez pela sensação, muitas vezes desconfortante, de algo ou alguém literalmente agarrar-se a essa parte do corpo. Talvez também esse sentido tenha sido construído pelo fato de que o pé não é convencionalmente um lugar onde se pega. Pegar na mão, por exemplo, dificilmente teria o sentido de chatear, aborrecer, visto que é previsível, pelas relações sociais e culturais, que as pessoas peguem na mão umas das outras para se cumprimentarem. Além disso, nessa construção estereotipada, verificase a comprovação da premissa cognitivista de que o pensamento é corporificado (JOHNSON, 1987), ou seja, a percepção que o ser humano tem do mundo está relacionada a suas características físicas. Observe-se que os dois elementos lexicais da construção pressupõem, respectivamente, atividade corporal e parte do corpo: o verbo pegar pressupõe uma ação com as mãos, e a palavra pé, por si só, já é parte do corpo humano.

Uma propriedade das construções idiomáticas iniciadas pelo verbo pegar é manifestada pela flexibilidade flexional desse verbo. Isso pode ser explicado pela variabilidade do primeiro argumento exigido pelo verbo e também pelas diferentes marcações de tempo em que os eventos se sucedem no mundo. Desse modo, é possível que o verbo apareça na primeira pessoa do singular, na terceira ou em uma das formas nominais: no gerúndio, no particípio ou no infinitivo. Em (7) o verbo aparece no particípio passado, auxiliado por ir:

(7) minha vó contava assim que a... que a minha bisavó era índia né... foi pegada no laço... e eles morava numa... numa fazenda... numa fazenda lá... e lá era muito afastado de vez em quando aparecia tal de índio lá escondido pegava eles colocava banana pra madurá... (Masc. 30)

Essa variação da forma verbal mostra que as construções com o verbo pegar são, de acordo com as distinções de Fillmore, Kay e O’Connor (1988), do tipo esquemáticas, visto que algum elemento ou os elementos são lexicalmente abertos.

Ao se dizer, por exemplo, pegar umas ondas ou pegar altas ondas ou ainda pegar ondas gigantes, não se desconstrói a metáfora nem o sentido da expressão, que é surfar, mas revela-se que ela está num grau menor de idiomaticidade do que aquela analisada nas amostras (5) e (6), pois não é produtivo dizer pegar no 
pé esquerdo ou pegar com jeito no pé, a ponto de a metáfora e o significado de chatear se conservarem.

Como já dito anteriormente, uma construção é transparente quando há "uma proximidade maior do cálculo do significado total da expressão por seus componentes" (VALE, 1999, p. 166). Já a opacidade é quando não há essa proximidade. Em (8) e (9), a seguir, por haver maior grau de transparência e menor grau de opacidade, torna-se possível recuperar o esquema imagético em que o argumento A é de alguma forma afetado pelo argumento B. A funciona como um contêiner, e B, em movimento único, se insere em A. Tanto a doença (dado 8) quanto a saúde (dado 9) "tomam" o sujeito e nele se instalaram:

(8) É... a gente passamos pelo rio Araguaia e fomo... aí era pra gente ficá noventa dias lá... a gente viemos com setenta e cinco dias... porque cinco dos que foram com nóis pegaram febre amarela... (Masc. 30)

(9) aí [a mãe] foi miorano... aí nó... ela foi pegano saúde... né... nóis cresceu... ajudô ela... nóis trabaiava... ajudava ela... (Fem. 28)

Diferentemente de (8) e (9), no dado (10), por haver maior grau de opacidade, torna-se mais complexa a tarefa de atribuir um dos seis esquemas imagéticos propostos por Sigiliano (2008) para o uso:

(10) ele [o pai] mim pegô no fraga... eu tava xingando... (Masc. 30)

Para o conjunto não composicional pegar no flagra, ${ }^{5}$ entendido como "ser surpreendido em situação constrangedora”, poder-se-ia propor, então, um esquema imagético, em que A vai em direção a $\mathrm{B}$ e o surpreende realizando $\mathrm{C}$ não convencional. O contêiner seria a relação estabelecida entre B e C.

Embora não tenham ocorrido no corpus, há ainda outras construções idiomáticas comuns no português brasileiro como pegar no ar, pegar de jeito, pegar firme, pegar descendo, pegar o boi. Dá-se atenção especial às duas últimas no que se refere à transparência e opacidade. Pegar descendo, que significa ir embora, constitui uma expressão mais transparente que pegar o boi, que significa

5 Há, também, no português brasileiro, a expressão pegar na boca da botija, que seria uma variação de pegar no flagra. 
fazer mais que o indivíduo merece. A primeira expressão tem maior grau de transparência pelo fato de que há aproximação semântica entre descer e ir embora, enquanto que a segunda tem maior grau de opacidade pelo fato de que não há relação de sentido entre o fato de pegar o boi e fazer mais que a pessoa merece, ou seja, não há, no significado global da construção, algo que remeta a agradar muito, a não ser que as origens situacionais do uso sejam explicitadas.

Como se pode observar em relação aos dados sobre construções idiomáticas do português contemporâneo falado em Goiás, estas se alinham às expressões idiomáticas encabeçadas pelo verbo pegar no português brasileiro. Além disso, em comparação com a literatura sobre o verbo pegar, percebe-se que esta investigação proporcionou conhecer um pouco mais sobre construções que possuem funções lexicais, uma vez que aquelas que possuem funções gramaticais, como as CFF peguei e falei, já têm sido amplamente descritas.

\section{Considerações finais}

Uma das grandes contribuições da linguística cognitiva para a descrição de fenômenos linguísticos como a idiomaticidade de construções encabeçadas pelo verbo pegar talvez seja a consideração de que não existem formas fixas e significados prontos. A variabilidade de significados do verbo pegar, associado a outros elementos linguísticos, é uma prova de que o verbo foi submetido a 'mutações' de significado, ao ser amplamente utilizado no meio sociocultural.

Outra contribuição é a consideração de que as formas e os significados possuem uma base sobre a qual surgem e evoluem. O corpo humano, juntamente com os aspectos culturais, é uma dessas bases. O verbo, objeto desse estudo, pressupõe, em seus sentidos mais básicos, o corpo. Esses sentidos, funcionalmente integrados com outros domínios, vão se abstraindo, apesar de sempre manterem a noção de movimento, que é própria do corpo humano.

A pesquisa revelou a alta frequência e rotinização do verbo pegar no corpus, o que sinaliza que, nos termos de Givón (1995), ele possui menor complexidade cognitiva e estrutural e isso contribui para que haja mudança de sentido e ampliação de funções lexicais e gramaticais.

Essa alta frequência de pegar possibilitou ainda identificar no corpus três tipos básicos, mas não definitivos: 1) verbo pleno, em que se conservam semelhanças estruturais e de significado com a forma-fonte; 2) encabeçador de construções 
idiomáticas, em que se observam ora maior ora menor grau de opacidade; 3 ) construções do tipo foi e fez, em que o falante faz uso do verbo pegar associado a outro verbo como forma de focalizar o objeto de V2 ou como forma de sequenciar o turno de fala. Essa variabilidade de usos revela que, cognitivamente, a linguagem é concebida como uma grande rede construcional, que ora apresenta abertura para formulação de construções, ora apresenta semiabertura e, por fim, apresenta restrições tanto sintáticas, quanto semânticas e pragmáticas.

Em relação às construções idiomáticas, especificamente, notou-se que algumas delas possuem maior grau de transparência, aproximando-se, em algum ponto, de seu sentido básico, como é o caso de pegar saúde, pegar febre amarela, pegar descendo. Outras possuem maior grau de opacidade, distanciando-se de seu sentido-fonte, como é o caso de pegar no flagra, pegar no pé, pegar o boi.

Assim, reconsidera-se aqui, como uma das limitações da pesquisa, aquilo que Croft e Cruse (2004) já haviam considerado: a ideia de que, por serem complexas e idiossincráticas, as construções idiomáticas não podem ser explicadas por regras gerais de sintaxe, semântica e pragmática. Cada uma delas possui suas propriedades de forma (fonológicas e sintáticas) e de significado e uso (semânticas e pragmáticas). Para os autores, elas devem ser analisadas segundo essas propriedades, levando-se em consideração que todas estão organizadas de maneira particular na mente do falante e podem ser acessadas pelo ouvinte, já que elas estão disponíveis na mente deste também.

Por outro lado, a pesquisa pode contribuir para o conhecimento e a divulgação de algumas propriedades das construções idiomáticas, resolvendo-se, dentro de seus limites, o problema de que tais construções constituem exceções sintáticas e que, portanto, até há pouco tempo não mereciam estudo. Assim, o estudo da conexão conceitual-cognitiva das construções idiomáticas contribui para que se perceba como a mente trabalha para conceber, aceitar, processar, armazenar, transformar e enviar informações relativas à linguagem. 


\title{
Idioms with verb "pegar": \\ a sociocognitive approach
}

\begin{abstract}
This paper aims to analyze the uses of the verb "pegar" idioms. The Data are of spoken language and they were collected in the corpus "Fala Goiana", recorded and transcribed by Functionalists Study Group of UFG. Data were analyzed considering the frequency of use, change of meaning, degrees of transparency and opacity and application of image schemes. The analysis was guided by theoretical considerations of cognitive linguistics. The results of this study revealed that the verb "pegar" has high frequency of use. This contributed to the widening its semantic status and its lexical and functional roles. The study also revealed that the idiomatic constructions sometimes have a low degree of opacity and sometimes a high one. The study may contribute to the expansion of the range of studies on linguistic features of idiomatic constructions in Brazilian Portuguese.
\end{abstract}

Keywords: Cognition. Construction. Idiomatic. Shift. Metaphorization.

\section{Referências}

BARRETO, Therezinha. Gramaticalização das conjunções na história do português. Tese (Doutorado em Letras) - Instituto de Letras, Universidade Federal da Bahia, Salvador, 1999.

BIZZOCCHI, Aldo. O darwinismo da linguagem. Língua Portuguesa, ano 3, n. 331, p. 56-58, jul. 2008.

BYBEE, Joan. Language, usage and cognition. Cambridge: Cambridge University Press, 2010.

CROFT, William; CRUSE, Alan. Cognitive linguistics. Cambridge: Cambridge University Press, 2004.

CUNHA, Antônio Geraldo da. Dicionário etimológico da língua portuguesa. 4. ed. revista e atualizada. Rio de Janeiro: Lexikon, 2010.

FERRARI, Lilian Vieira. Linguística cognitiva e o realismo corporificado: implicações filosóficas e psicológicas. Veredas, Juiz de Fora, v. 5, n. 2, p. 23-29, 2009. 
FILLMORE, Charles J.; KAY, Paul; O’CONNOR, Mary. Catherine. Regularity and idiomaticity in grammatical constructions: the case of let alone. Language, v. 64, n. 3 , p. $501-538,1988$.

GIVÓN, Talmy. Functionalism and grammar. Amsterdam/Philadelphia: John Benjamins, 1995.

GONÇALVES, Sebastião Carlos Leite; LIMA-HERNANDES, Maria Célia; CASSEB-GALVÃO, Vânia Cristina (Org.). Introdução à gramaticalização: princípios teóricos e aplicação. São Paulo: Parábola, 2007.

JOHNSON, Mark. The body in the mind: the bodily bases of meaning, imagination, and reason. London: The University of Chicago Press, 1987.

LANGACKER, Ronald W. A study in unified diversity: English and Mixtec locatives. In: ENFIELD, N. J. Etnosyntax. New York: Oxford University Press, 2002.

NEVES, Maria Helena de Moura. A gramática: história, teoria e análise, ensino. São Paulo: Editora UNESP, 2002.

NUNBERG, Geoffrey; SAG, Ivan A.; WASOW, Thomas. Idioms. Language, v. 70, n. 3, p. 491-538, Sep. 1994.

OLIVEIRA, Mariangela Rios de; ROSÁRIO, Ivo da Costa do (Org.). Linguística centrada no uso: teoria e método. Rio de Janeiro: Lamparina; FAPERJ, 2015.

RODRIGUES, Angélica T. C. "Eu peguei e saí": uma construção nos limites da coordenação. Veredas, Juiz de Fora, n. 1 e n. 2, p. 29-40, jan./dez. 2004.

RODRIGUES, Angélica T. C. "Eu fui e fiz esta tese". As construções do tipo foi e fez no português do Brasil. Tese (Doutorado) - Universidade Estadual de Campinas, Campinas, 2006.

SIGILIANO, Natália Sathler. A mudança semântica do verbo "pegar" frente à conexão de cláusulas. 2006. Disponível em: $<$ http://dlcv.fflch.usp.br/sites/dlcv. fflch.usp.br/files/ 06_4.pdf>. Acesso em: 25 jul. 2016.

SIGILIANO, Natália Sathler. "Eu peguei e falei: eu vou!": as noções de movimento e mudança nas construções com o verbo "pegar". Estudos linguísticos, São Paulo, v. 37, n. 1, p. 243-251, jan./abr. 2008. 
SILVA, Leosmar A. da. As bases corporais da gramática: um estudo sobre conceptualização e metaforização no português brasileiro. 2012. 284 f. Tese (Doutorado em Estudos Linguísticos) - Faculdade de Letras, Universidade Federal de Goiás, Goiânia, 2012.

VALE, Oto Araújo. Expressões cristalizadas: transparência e opacidade. Signótica, Goiânia, v. 11, n. 1, p. 163-172, jan./dez. 1999.

Recebido em 30/03/2016.

Aceito em 05/07/2016. 